\title{
The Use of Technology in Accounting Classrooms During COVID-19: What Do Accounting Teachers in the Eastern Cape, South Africa, Have to Say?
}

\author{
Melikhaya Skhephe ${ }^{* 1}$ \& Martha Matashu² \\ *Corresponding Author: sikepemk@gmail.com \\ 1. North West University, South Africa \\ 2. North West University, South Africa \\ Received : 2021-05-25 \\ Revised : 2021-08-04 \\ Accepted : 2021-08-26
}

doi $10.46303 /$ ressat.2021.30

\begin{abstract}
How to cite this paper: Skhephe, M. \& Matashu, M. (2021). The Use of Technology in Accounting Classrooms During COVID-19: What Do Accounting Teachers in the Eastern Cape, South Africa, Have to Say? Research in Social Sciences and Technology, 6(2), 267-278. https://doi.org/10.46303/ressat.2021.30
\end{abstract}

This is an Open Access article distributed under the terms of the Creative Commons Attribution 4.0 International license (https://creativecommons.org/licenses/by/4.0/).

\begin{abstract}
It was mentioned that accounting classrooms must keep pace with rapidly changing technology, which is influencing all aspects of our daily lives. This study examined accounting teachers' views on the use of technology in their classrooms during Covid-19. To this end, the researchers employed a qualitative approach and a case study. Data were obtained from accounting teachers through interviews, with the sample of ten participants having been purposively selected. The results indicated that allowing learners to bring their own personal technological devices to the classroom represented a contravention of the school's constitution. Another result was that when technology is optimally used in the classroom, it makes available different forms of assistance which change the way learners learn. Researchers conclude that use of technology in accounting implemented compulsory if teachers want to keep up with changes accounting profession. Furthermore, schools' constitutions need to be amended to promote the use of available technologies in the classroom, albeit in a highly structured, managed, and efficient way. Researchers recommend that learners be allowed to use their own personal devices in the classroom, to enhance learning. School principal be encouraged to develop school plans outlining how s/he would support use of technology in school.
\end{abstract}

Keywords: Accounting classrooms, teachers' views, educational technologies, ICT in education, COVID-19, South Africa 
Skhephe, M. \& Matashu, M., The Use of Technology in Accounting Classrooms During COVID-19: What Do Accounting Teachers in the Eastern Cape, South Africa, Have to Say?

\section{Introduction}

Oliveira (2015) opines that, for accounting classrooms to remain relevant, continuous changes and improvements are necessary in the subject area. What this means, is that teaching and learning processes must keep up with the technological innovations which professional accountants are adopting. Babalola and Tiamiyu (2014) concur that for Accountancy learners to acquire the weights and potentials connected with heightened worldwide competition, a variety of basic skills is needed - amongst others, diagnostic and problematic-solving skills; personal and interactive skills; management-related, negotiation and organizational skills; together with the capacity to apply these competencies in an array of single situations, often with the aid of technology. Obeng (2014) asserts that technology use in accounting classrooms is now deemed to be as crucial a usefulness as water and electricity in communities, and later has also come to play a major role in education. Importantly, technology permits continuous testing to determine whether learners have mastered the contents of the materials presented to them (Hammond, 2013). Beetham and Sharpe (2013) asserts, great majority of schools in the United Kingdom are virtual learning environments (VLEs), thanks to the use of Web 2.0 or 'soft software', Sakai and DrupalEd, Moodle, Blackboard, Turnitin and many more. Furthermore, these platforms grant teachers the opportunity to search topics on the internet, track their learners' activities display syllabus information. However, In the Eastern Cape of South Africa, Daily Dispatch (2020) reveals that a contract worth hundreds of millions of rand, to lease 55 000 tablet devices, was signed to provide a technology use in classrooms. Thus far, 44000 tablets have been delivered to learners, in an attempt to promote online, distance learning and laptops distributed to teachers. Despite these impressive statistics, a study conducted by Skhephe, Caga et al. (2020) reveal that there is no evidence that the recipients were prepared, in any way, before being allocated these devices. Therefore, it is against this background that the authors wanted to investigate, about the use of technology in accounting classrooms during covid-19.

\section{Research questions}

The study was guided by the following research questions

- Why accounting teachers, must embrace technology use during and after the Covid-19?

- How does technology use assist in the teaching of accounting during Covid-19?

\section{Review of literature}

Literature review is a critical, analytical account of the existing research on a part (Maree, 2015).

The digital revolution has changed the way accounting teachers are expected to deliver their lessons in their respective classrooms (Skhephe, Mantlana et al., 2020; Tadeu et al., 2019). Furthermore, in the 21 century a lot of information is now available via technology than any one person could ever hope to acquire. In this study literature on the use of technological skills in accounting classroom has been reviewed under the separate sub-headings.

\section{Technology in the accounting classroom}

Accounting classroom has changed to fulfil business necessities, better prepare learners for the labor marketplace and to allow them to thrive in a changing environment (Yap et al., 
Skhephe, M. \& Matashu, M., The Use of Technology in Accounting Classrooms During COVID-19: What Do Accounting Teachers in the Eastern Cape, South Africa, Have to Say?

2014). The most recent cohorts of accounting learners are more familiar with diverse technologies - after all, they learnt to deal with mobile phones, tablets, and individual technology from an initial stage. accounting teachers must take benefit of these valency to instrument incremental variations aimed at developing certain strengths which are inherent in learners, such as teamwork skills and enthusiasm, as these competencies will enable them to make a difference in their organizations one day, to communicate efficiently with supervisors and to be at ease with technology (Mastrolia \& Willits, 2013). The current organizational atmosphere entails professionals to progress innovative skills which, if schools have the foresight, they will already have trained their learners to master. As Mastrolia and Willits (2013) observe, related skills must comprise the capability to search a widespread variation of bases (e.g., the world wide web) and to effort with an extensive variety of data services (Albrecht \& Sack, 2016). Worryingly, Yu et al. (2013) note that accounting learners are not adequately prepared to use databases or technology domains, nor do they become proficient at problem solving. Yu et al. (2013) emphasizes that, as the world prepares to meet the demands of $4 \mathrm{IR}$, it will become very problematic to teach Accountancy exclusive of the usage of detailed software.

\section{Reimbursements of consuming technology in the accounting classroom}

Babalola and Tiamiyu (2014) opine that the appropriate use of technology in accounting classrooms can catalyze a model modification in terms of both content and pedagogy, which will, in turn, usher in reforms. Babalola and Tiamiyu (2014) further argue that, if considered and applied appropriately, technology-reinforced teaching can foster the gaining of appropriate knowledge and skills to form a basis from which to empower accounting learners for lifelong learning. Babalola and Tiamiyu further observe that, there are several benefits that can be derived from the use of technology in accounting classrooms, as discussed below.

Evaluative learning: Technology permits pupils to (actively) reconnoiter and determine, rather than merely (passively) attend and recall. Technology-improved knowledge is learner-focused and investigative, unlike static, text- or print-based educational aids. It recognizes that there are many diverse knowledge pathways and diverse arrays of articulations of knowledge.

Dynamic learning: Technology-improved knowledge mobilizes tools through which to examine, calculate and analyze material, thus affording a platform for learner inquiry and analysis, and facilitating the construction of new information. Pupils consequently acquire while doing, and, where suitable, effort on real-life difficulties in complexity, assembly learning less intellectual and more applicable to their lifetime condition.

Co-operative learning: Where technology supports learning, it inspires collaboration and teamwork among pupils, educators, and specialists, notwithstanding of where in the world they are. Away from each other from modelling actual-world connections, technologyreinforced education offers pupils and chance to work with individuals from various nations, in that way helping to develop their team up and forthcoming skills, as well as their worldwide responsiveness. It models education done through the learners' generation, by enlarging the learning space to incorporate not only their peers, but also mentors and specialists from diverse disciplines. 
Skhephe, M. \& Matashu, M., The Use of Technology in Accounting Classrooms During COVID-19: What Do Accounting Teachers in the Eastern Cape, South Africa, Have to Say?

Creative learning: Learning which is maintained by technology endorses the guidance of present data and the formation of real-world products, rather than the regurgitation of established data.

Integrative learning: Here, the goal is to promote a thematic, consolidative method to education and knowledge. Such a method removes the artificial divide amongst diverse disciplines, and amongst theory and practice that characterizes the old-style classroom approach.

\section{Employing accounting software in the teaching and learning of accounting}

Wan et al. (2016) explain that, in using relevant computer software and technology in accounting classrooms a new type of learning environment is created, which offers an alternative platform for teaching and learning. As Wan et al. (2016) point out, traditional approaches are usually blamed for producing accounting learners who have good technical abilities but lack the relevant skills and expertise. The demands of the ever-evolving business environment made certain changes imperative - changes in the way in which accounting knowledge and skills are taught to, and developed in, learners. Accounting teachers may be described as agents of knowledge transfer and skills providers, and they should thus exploit the potentials of any devices, platforms or aids which can benefit their classroom practice and help their learners. As Wan et al. (2016) add, due to their flexibility and embedded special features, the delivery methods available in computer-assisted technology make learning more attractive and effective. However, teachers of accounting should not solely depend on impressive software to deliver subject-related knowledge to their learners. As Connell (2011) argue, an over-reliance on software might enhance learners' enjoyment of the subject and improve their marks, but it may also prevent them from attaining those learning outcomes which require an understanding basic accounting procedures and concepts. In the view of Connell et al., (2011), accounting software should be treated like a "transparent box", requiring users to first understand the contents of the knowledge they must learn, before they use the system.

\section{E-readiness accounting classroom}

E-readiness classroom is one which is designed especially for the delivery and support of electronic learning systems (ELSs) (Lloyd, Byrne, and McCoy 2012). Lloyd et al. (2012) asserts that, where such classrooms exist, the teacher's job is to instruct learners to work on their own, while his/her role is to guide the learners throughout-this is where teaching is supported by technology, often in the form of a connection to the internet. For Keramati et al. (2011), the e-readiness of an accounting classroom is determined on three levels: technical readiness, lifestyle readiness and pedagogical readiness. Technical readiness is where the focus is on the readiness of technology hardware, software, and a connection to the internet, as all these aspects support e-learning. In lifestyle readiness, the focus is on the facilitator and related challenges which may affect his/her satisfaction with an e-learning community, for instance his/her in/ability to adapt to change (Panda \& Mishra, 2013). Pedagogical readiness places the emphasis on the facilitator's understanding of technology, and his/her experience, confidence, and attitude (Dursun et al., 2011). Sammak et al. (2010) asserts that pedagogical readiness pertains to perceptions regarding the electronic learning systems and evaluates 
Skhephe, M. \& Matashu, M., The Use of Technology in Accounting Classrooms During COVID-19: What Do Accounting Teachers in the Eastern Cape, South Africa, Have to Say?

whether facilitators have a predisposition to embrace new technology to accomplish different related tasks. Holsapple and Lee-Post (2010) believe that, in terms of pedagogical readiness, it is crucial to assess whether a facilitator prefers a chalk-and-talk approach to the optimal use of technology.

\section{Theoretical framework}

Based on global expectations, and changing realities related to the way in which technology influences teaching in the era of 4IR, Davis et al. (1989) developed the technology acceptance theory (TAT). Having considered the stated research questions, the researchers who authored this Study deemed TAT ideal for underpinning their investigation, which is reported on here. TAT is used to predict or determine why someone might use technology, while another individual may decline to do so (Davis et al. 1989). This theory further states that, for technology to be accepted, user's necessity to advance innovative skills and knowledge of present technologies, by continuously improving their capacities and upgrading their skills (Davis et al. 1989). Implementing the necessary changes is, however, quite a challenge. Many factors, including the high cost of technology adoption and skills-related differences in the users of those technologies, may represent barrier to uptake which need to be overcome and turned into opportunities (Davis et al. 1989). Furthermore, to keep abreast, decision makers also need to capitalize on the opportunity to make technology dispersal and placement as achievement. Straub et al. (2015) observe that a potential user's educational upbringing, views and individual biases are all influences that disturb the receiving (or rejection!) of newly presented and/or moved technologies. The amount of information circulating today, across millions of information structures, is so massive that it is impossible to operate data without the aid of various technologies. However, an information system which delivers high technical performance will be useless if the user, for whatever reason, does not adopt and/or accept the available technology. As per TAT, we necessity to comprehend the details because users outright admit or initially discard certain structures, and then, in the case of the latter, grudgingly adapt systems to suit their needs and those of their learners. Venkatesh et al. (2015) opine that technological innovations need to be not merely accepted, but actually used. This theory is applicable in the present study, since the mode of delivery of information in the classroom is continuously shifting, the legitimacy and correctness of content might modification over time, dependent on the finding of new facts and/or breakthroughs being made in a subject. TAT is very relevant to this study, since it is a material classifications theory that examines how users originate to receive and use technology. Furthermore, the actual system envisages an endpoint, in other words what every user should be able to do with technology. This theory further proposes that when operators are offered with an innovative technology, several issues impact their choice about how and when to use it, while the capability to know is taken to be more serious than what is really acknowledged (Davis et al. 1989). 
Skhephe, M. \& Matashu, M., The Use of Technology in Accounting Classrooms During COVID-19: What Do Accounting Teachers in the Eastern Cape, South Africa, Have to Say?

\section{Methodology}

\section{Research design}

The study uses of the qualitative approach. The goal of this method is to uncover actual inner meanings and new ideas (Leavy, 2017). In order to investigate the use of technology in accounting courses during Covid-19, this study employs a qualitative approach to acquire highquality data and interesting insights using semi-structured interviews. The outline, plan, or method that will be employed to get an answer to the research questions is defined by Johnson and Christensen (2008). A case study is used in this study. A case study is a research project that details and analyses one or more cases (Denscombe, 2010). The case study is on the 5 secondary school in the Eastern cape of South Africa. As the authors mentioned that they have analyze the data using constant comparative method, we have adapted the expert the we have mentioned in the data analysis.

\section{Sample}

The sample consisted of 10 accounting teachers. Participants were purposive selected based on being accounting teachers who are expected to make use of technology. All of the participants were between 5 to 15 years of teaching experiences. Five of the teachers were women and five were men.

\section{Data collection}

Interviews were employed to gather data for this study. Bogdan and Biklen (2007) defines interviews as a conversation between two or more people that is moderated by one person with the goal of obtaining information from the other people. They were semi-structured interviews. However, it is important to mention that since the study was conducted during the Covid-19 pandemic, interviews were conducted online in order to comply with Covid-19 protocols. Each interviewer was give 10 minutes to respond to all the questions. A tape recorder was used to record the responses of the interviewer and after all the interviewers were interviewed, the authors transcribed interviewer's response and verbatim accounts were used.

\section{Data trustworthiness}

According to Creswell (2014) it about qualitative information that is unchanging, foreseeable, reliable, dependable, and unfailing in the future, generating the similar findings or outcomes as before. The study followed Creswell's four qualitative research characteristics of dependability, confirmability, and repeatability.

\section{Data analysis, interpretation and reporting}

This study used a constant comparison technique to data analysis, which is consistent with qualitative research (Gray, 2018). In this approach, data was reviewed and reread as it was collected, and the authors identified emergent patterns through a process of inductive reasoning. Then, as new data was gathered, social phenomena were categorized and their attributes noted, and instances were compared. This form of analysis will fit to answer the research questions since each interpretation and finding is compared with existing findings as 
Skhephe, M. \& Matashu, M., The Use of Technology in Accounting Classrooms During COVID-19: What Do Accounting Teachers in the Eastern Cape, South Africa, Have to Say?

it emerges from the data analysis. Another import element of this approach is that the research begins with raw data; through constant comparisons a substantive theory will emerge.

\section{Ethical procedures}

De Vos et al. 2011) believes that researchers need to be aware of what is considered as proper and improper in scientific research. The investigators detected entirely proper measures before and during the study. Right permission was established from the researcher's organization. The investigators were allowed by the Eastern Cape Education District to evaluate schools and interview contributors. The doorkeepers were employed to gain access to the investigative sites and the participants. The selected members were guaranteed that the data was only for study tenacities. The matters of informed agreement and privacy were obeyed as well.

\section{Results}

\section{Embracing the use of technology in the accounting classroom during and after the covid-19}

The findings show that teachers are trying hard to embrace use technology in their classrooms. However, technology adoption and use are facing multiple challenges and is proceeding at a snail's pace. The following were the responses from the participants. Teacher 2 confirmed: In the $21^{\text {st }}$ century there is no way that I cannot embrace the use of technology in my classroom. Since there is no functioning computer laboratory at my school to utilize for searching and googling with my accounting learners, other than the laptops [which] were given to all teachers [which I use] as personal technology), I am allowing accounting learners to bring their own personal technology devices to the classroom, in order to allow searching/googling of accounting information. I [monitor] their progress, but we are struggling with internet since these learners are mostly using their own data to search, and they complain that data is expensive.

Teacher 3 stated:

I am making use of my own laptop and the data projector I bought by myself whenever, I am in my classroom. Jah it is assisting in the classroom, but I can see my head of department and the principal are not supporting me. You cannot believe that whatever, I need technology device I need I use my own money to buy it.

Teacher 7 confirmed this:

Looking into the changes that are happening in [the] accounting curriculum and looking into the type of learners we teach; technology use within the classroom is un-avoid[able]. In my classroom, just [by] mentioning the [word] use of technology [all] my learners become excited, and it improves their participation in the classroom. However, since there are no computer technologies for learners in the form of computer laborator[ies] in the school, I [have] allow[ed] the accounting learners to carry their device[s] and use them in the classroom. [It] is prohibit [ed by] the constitution of the school, [but] only allowed in [the] accounting classroom, not in other subjects.

Teacher 10 added: 
Skhephe, M. \& Matashu, M., The Use of Technology in Accounting Classrooms During COVID-19: What Do Accounting Teachers in the Eastern Cape, South Africa, Have to Say?

In my school, I putt a pressure to the school managers to fix all the computers that were supplied by the department of basic education in 2010 and I am conducting my accounting classes there.

\section{Assistance provided by technology use in accounting classroom during Covid-19.}

The findings indicated that, when technology is in use in the accounting classroom, teaching becomes easy since all the parties work towards one goal of achieving results.

Teacher 1 confirmed:

When technology is in [the] accounting classroom, it provides different opportunities to make learning more fun and enjoyable, in terms of teaching [the] same things in new ways. Apart from that, we need to acknowledge that no one learns in the same way, because of different learning styles and different abilities. So, through technology use within the classroom, those things are catered [for].

Teacher 4 reveal:

Lastly, technology can encourage collaboration with learners in the same classroom, [the] same school and even with other classrooms around the world.

Teacher 5 added:

It makes my learners to learn independent and it increases completion since it proves my learners with more information in addressing or answering one question.

Teacher 8 concurs:

Due to [my] love of both accounting and technology, I am trying my best in my classroom to make use of technology, but it [would] be better if education district officials [did] follow-up [visits] to each school, [to see] how teachers make use of these laptops. That [would have] served to pressurize teachers to make use of [the] technologies allocated to them, and in that way, benefits associated [with] the use of technology were going to be achieved.

Teacher 9 stated:

Using any form of technology in the classroom changes the way learners learn and also how teachers teach, learners are not being forced to learn.

\section{Discussion}

In this study, the findings arrived at after data interpretation and analysis were examined in the light of the identified themes and categories.

\section{Embracing the use of technology in the classroom}

The findings revealed that accounting teachers are extremely willing to embrace and support the use of technology in their classrooms, as is evident from the fact that they allow their learners to bring their own personal devices to use as learning aids. As the participants admitted, however, they are confronted by challenges such as the high cost of data and a school constitution which prohibits the possession and use of cell phones on the school 
Skhephe, M. \& Matashu, M., The Use of Technology in Accounting Classrooms During COVID-19: What Do Accounting Teachers in the Eastern Cape, South Africa, Have to Say?

premises. This finding confirms Mastrolia and Willits' (2013) argument that the youth are extremely familiar with the latest gadgets and technologies - many masters the use of mobile phones, tablets and personal computers as infants or toddlers. accounting teachers must capitalize on those skills, to introduce incremental changes in the classroom. Rather than focusing on individual strengths, the emphasis should shift to teamwork and to early adopters motivating their peers who might not be as comfortable with such devices yet. Rather than being a nice-to-have, technology should serve to strengthen learners' problem-solving skills (Yu et al. 2013). As Davis et al. (1989) propose, all learners must be encouraged to develop new skills and knowledge of current technology, and continuously upskill themselves and broaden their repertoire of abilities. Oliveira (2015) believes allowing learners to make use of their own personal devices in the classroom can save schools the costs of buying hardware and software, given their already constrained budgets. Oliveira further argue that not allowing such devices on the premises risk learners being left behind and will mean they cannot keep up with platforms which have been made available to assist them in their learning. These findings concur with Skhephe, Mantlana et al. (2020) that learners are already au fait with most devices, and these technological tools offer teachers a wonderful opportunity to enhance their teaching, while allowing learners to access a variety of platforms to enrich their learning.

\section{Assistance provided by technology use in accounting classroom}

From the interviews it became clear that accounting teachers understand that when technology is optimally used in class, it provides different forms of assistance: it not only changes the way in which learners learn, but also the way in which the teacher delivers his/her lesson. This finding corroborates the view of Babalola and Tiamiyu (2014) that the appropriate use of technology in the accounting classroom can bring about a paradigm shift in both the content and pedagogy which the teacher uses, and that is the essence of true classroom reform. As Wan et al. (2016) note, it is crucial to use relevant computer software and technology, to create a learning environment that fosters teaching and learning to the extent that other subjects may be inspired to try to do the same - that will boost learners' proficiency across all disciplines. Indeed, as Connell et al. (2014) argue, teachers should be careful not to rely so much on software that the most basic learning outcomes and foundational concepts are ignored. As Davis et al. (1989) warn, technology implementation is a costly undertaking, and teachers should be aware that not all learners can afford the same software or have the same level of competence to start with. This finding corroborate with Davis et al finding that teachers need to understand the reasons why users outright accept or initially reject certain systems, and then, in the case of the latter, grudgingly adapt systems to suit their needs and those of their learners.

\section{Implications for policy and practice}

This study showed that use of technology in accounting classrooms plays a pivotal role in equipping learners with the modern skills needed in accounting profession. However, proper implementation of technology use confronted with many challenges. Therefore, teachers and education managers should develop their own operational plans, guidelines, indicators and strategies for proper implementation of technology use in accounting classrooms. In addition, curriculum managers should work with relevant stakeholders to refine and implement draft 
Skhephe, M. \& Matashu, M., The Use of Technology in Accounting Classrooms During COVID-19: What Do Accounting Teachers in the Eastern Cape, South Africa, Have to Say?

policies that are available in the Eastern Cape Province to ensure the enough discussion forums for teachers and principals are open to voice their views around use of technology across all subject in schools.

\section{Conclusion}

This research investigated the use of technology in accounting classrooms during covid-19. To this end, the researchers focused on high schools in the Eastern Cape province of South Africa. They concluded, after a critical review of the findings, that there is an urgent need to ensure that use of technology in accounting implemented compulsory if teachers want to keep up with changes accounting profession. Furthermore, schools' constitutions need to be amended to promote the use of available technologies in the classroom, albeit in a highly structured, managed and efficient way. Although it is not easy to adapt to change, if teachers realize the benefits of using technology, they will concede that most learners are glued to their technologies, rather than textbooks.

\section{Limitations of the study}

This study has some limitations that were considered when interpreting its findings. Firstly, this study is limited to high school accounting teachers in the Eastern Cape Province, South Africa. Secondly, this study adopted a qualitative approach that included accounting teachers with interviews to establish a baseline of teachers use of technology use in the classroom. However, the research could have more validity if this study adopted mixed methods of quantitative approach to reveal technology implementation in high schools by teachers in the Eastern Cape, South Africa.

\section{Recommendations}

Researchers recommend that learners should be allowed to make use of their own personal devices in the classroom, with strict provisos, where schools are unable to provide such technologies to their learners - in that way, no child will be left behind. School principal be encouraged to develop school plans outlining how s/he would support the structured, meaningful use of technology in their school. ICT officials from all education district offices conduct workshops with teachers who have been allocated laptops or tablets, so that they may learn how to use those technologies as a tool to supplement their teaching.

\section{References}

Albrecht, W., \& Sack, R. (2016). Accounting education: Charting the course through a perilous future. Sarasota: American Accounting Association.

Babalola, Y. A., \& Tiamiyu, R. (2014). The use of ICT in teaching and learning of Accounting education in Nigeria. 33rd Annual Convention and International Conference of Nigeria Association for Educational Medial and Technology (NAEMT) at Emmanuel Alayande College of Education, Oyo State, Nigeria, October 8-12, 2012, Available at: https://ssrn.com/abstract=2181366

Beetham, H. \& Sharpe, R. (2013). Rethinking Pedagogy for a Digital Age: Designing for $21^{\text {st }}$ Century Learning ( $2^{\text {nd }}$ ed.). New York: Routledge. 
Skhephe, M. \& Matashu, M., The Use of Technology in Accounting Classrooms During COVID-19: What Do Accounting Teachers in the Eastern Cape, South Africa, Have to Say?

Bogdan, R. C., \& Biklen, S.K. (2015). Qualitative research of education: An introduction to theories and methods. Boston: Allyn \& Bacon.

Connell, A, M. (2011). The potential of ICT based education in developing countries. New York: Education Development Centre.

Davis, F. D., Bagozzi, R. P., \& Warshaw, P. R. (1989). Perceived usefulness, perceived ease of use and user acceptance of information technology. MIS Quarterly, 13 (10), 318-333.

De Vos, A., Strydom H., Fouché., C. \& Delport, C. S. L. (2011). Research at Grassroots. Pretoria: Van Schaik.

Department of Education (DoE). (2010). Revised National Curriculum Statement, Grades R-9 (schools): Teacher's guide for the development of learning programmes. Pretoria: Government Printer.

Denscombe, M. (2010). The Good Research Guide for Small Scale Research Projects. Buckingham: Open University Press

Dursun, A., Effie, L. \& Law, C. (2011). Measuring Student E-Learning Readiness: A Case about the Subject of Electricity in Higher Education Institutions in Turkey. Conference: Advances in Web-Based Learning-ICWL 2011-10 ${ }^{\text {th }}$ International Conference, Hong Kong, China, December 8-10, 2011. Proceedings.

Gray, A. (2018). Effective Differentiation: A Training Guide to Empower Teachers and Enable Learners with SEND and Specific Learning Difficulties. Texas: Routledge.

Hammond, M. (2015). Introducing Information Communications Technology in schools in England: Rationale and consequences. British Journal of Educational Technology, 45 (6), 50-62.

Holsapple, C. W., \& Lee-Post, A. (2006). Defining, assessing, and promoting e-learning success: An information system perspective. Sciences Journal of Innovative Education, 4(1), 67-85. https://doi.org/10.1111/j.1540-4609.2006.00102.x

Johnson, R. B., \& Christensen, L. B. (2013). Educational Research: Quantitative, Qualitative, and Mixed Approaches. Lose Angeles: Sage Publications.

Keramati, A., Afshari-Mofrad, M., \& Kamrari, A. (2011). The role of readiness factors in Elearning outcomes: An empirical study. Computers and Education. 1 (9), 20-35

Leavy, P. (2017). Research Design. Quantitative, Qualitative, Mixed Methods, Arts Based and Community Based Participatory Research Approaches. New York: Gilford Press.

Lloyd, S A., Byrne, M. M., \& McCoy, T.S. (2012). Faculty-perceived barriers of online education. Journal of Online Learning and Teaching, 8 (1), 1-12.

Magwa, S. \& Magwa, W. (2015). A Guide to Conducting Educational Research: A Student Handbook. Singapore: Strategic Book Publishing and Rights Co. LLC

Maree, K. (2015). First steps in educational research. Pretoria: Van Schaik.

Mastrolia, S. A., \& Willits, S.D. (2014). Millennials: What do we really know about them? Journal of Advances in Accounting Education, 14 (9), 45-60.

Obeng, T. K. (2014). Practical Application of ICT t Enhance University Education in Ghana, http://www.modernghana.com/Ghana/tome/News.Achive/features.asp [accessed 10 February 2021].

Oliveira, H. C. (2015). Technology in Accounting education: A business simulation case study. Porto: ISCAP Polytechnic Institute. 
Panda, S. \& Mishra, S. (2013). E-learning in a mega open university: Faculty attitude, barriers and motivators. Educational Media International, 44(4): 323-338. https://doi.org/10.1080/09523980701680854

Sammak, M. S., Baghbel, M. \& Samancioglu, M. (2010). Technology readiness of primary teachers: A case study in Turkey. Procedia Social and Behavioral Sciences, 2(10): 26712675. https://doi.org/10.1016/j.sbspro.2010.03.393.

Skhephe, M., Caga, N. P. \& Boadzo, R. M. K. (2020). Accounting teachers' readiness for eLearning in the Fourth Industrial Revolution: A case of selected high schools in the Eastern Cape, South Africa. Perspectives in Education. 38(1), 43-57 http://dx.doi.org/10.18820/2519593X/pie.v36i2

Skhephe, M., Mantlana, C. D., \& Gobingca, B. Z. (2020). Accounting learner readiness for virtual classrooms in the Eastern Cape, South Africa: Lessons learnt from the literature. Proceedings of the 2nd World Conference on the Future of Education (Brussels, Belgium), p. 1-12.

Straub, D., Lock, K., \& Hill, C. (2015). Transfer of information technology to developing countries: A test of cultural influence modeling in the Arab world. Journal of Global Information Management, 9 (5), 6-20.

Tadeu, P., Fernandez Batanero, J., \& Tarman, B. (2019). ICT in a Global World. Research in Social Sciences and Technology, 4(2), i-ii. https://doi.org/10.46303/ressat.04.02.ed

Venkatesh, V., Morris, M. G., Davis, G. B., \& Davis, F. D. (2015). User acceptance of information technology: Toward a unified view. MIS Quarterly, 27 (7), 15-30.

Wan, W. M. N., Kassim, C. K. H. C. K., Mohd Nasir, N. E. \& Suraya, A. (2016). The use of Accounting software for effective teaching and learning of introductory Accounting: A pedagogical discussion. Journal of Social Science, 11 (3), 100-115.

Yap, C., Ryan, S., \& Yong, J. (2014). Challenges facing professional Accounting education in a commercialized education sector. Journal of Accounting Education, 6 (2), 50-65.

Yu, S., Churyk, N. T., \& Chang, A. (2013). Are students ready for their future Accounting careers? Insights from observed perception gaps among employers, interns and alumni. Global Perspectives on Accounting Education, 10 (7), 1-15. 